IJRDM

47,7

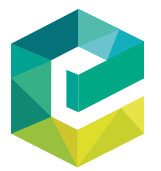

International Journal of Retail \& Distribution Management Vol. 47 No. 7, 2019 p. 772

(C) Emerald Publishing Limited 0959-0552

DOI 10.1108/IJRDM-07-2019-298

\section{Publisher note}

The publisher would like to inform readers that several special issue papers have mistakenly published as part of regular issues. This error was introduced as part of the editorial process, and the publisher sincerely apologizes for this error. The papers will remain in their current issues. A comprehensive list of papers affected is as follows.

The following papers were originally intended to publish as part of "Physical and Digital Market Places - Where Marketing meets Operations" guest edited by Christoph Teller:

- Milan Jocevski, Niklas Arvidsson, Giovanni Miragliotta, Antonio Ghezzi and Riccardo Mangiaracina (2019), "Transitions towards omni-channel retailing strategies: a business model perspective", International Journal of Retail \& Distribution Management, Vol. 47, No. 2, doi: 10.1108/IJRDM-08-2018-0176.

- Humberto A. Brea-Solís and Emili Grifell-Tatjé (2019), "A business model analysis of Kmart's downfall”, International Journal of Retail \& Distribution Management, Vol. 47, No. 2, doi: 10.1108/IJRDM-10-2018-0218.

The following papers were originally intended to publish as part of "ACRA 2017: Best Papers: Retail shopper/customer experience?" guest edited by Hyunjoo Im and Sejin Ha:

- Hyunjoo Im and Claire Whang (2018), "Does recommendation matter for trusting beliefs and trusting intentions? Focused on different types of recommender system and sponsored recommendation", International Journal of Retail \& Distribution Management, Vol. 46, No. 10, doi: 10.1108/IJRDM-06-2017-0122.

- Yulia Vakulenko, Daniel Hellstrom and Pejvak Oghazi (2018), "Customer value in self-service kiosks: a systematic literature review”, International Journal of Retail \& Distribution Management, Vol. 46, No. 5, doi: 10.1108/ IJRDM-04-2017-0084.

- Marco Ieva and Cristina Ziliani (2018), "Mapping touchpoint exposure in retailing: implications for developing an omnichannel customer experience", International Journal of Retail \& Distribution Management, Vol. 46, No. 3, doi: 10.1108/IJRDM-04-2017-0097.

- Eugene Wong and Yan Wei (2018), "Customer online shopping experience data analytics: integrated customer segmentation and customised services prediction model”, International Journal of Retail \& Distribution Management, Vol. 46, No. 4, doi: 10.1108/IJRDM-06-2017-0130.

- Watson, A., Alexander, B. and Salavati, L. (2018), "The impact of experiential augmented reality applications on fashion purchase intention", International Journal of Retail \& Distribution Management, Vol. 48, No. 5, doi: 10.1108/IJRDM-06-2017-0117.

The following papers were originally intended to publish as part of "Franchising: The Performance Question" guest edited by Jacques Boulay:

- Ilan Alon and B. Elango (2018), "Franchising and initial public offering: a signaling perspective”, International Journal of Retail \& Distribution Management, Vol. 46, Nos 11/12, doi: 10.1108/IJRDM-10-2017-0240.

- Nabil Ghantous and Shobha S. Das (2018), "International franchising and performance: a resource-based perspective", International Journal of Retail \& Distribution Management, Vol. 46, No. 8, doi: 10.1108/IJRDM-10-2017-0244.

$\overline{\text { The publisher would like to take this opportunity to thank the guest editors for their time and effort. }}$ 